\title{
How to Test Location-based Mobile Apps
}

\author{
Jing Cheng \\ School of Computer Science \\ Northwest Polytechnical University, \\ Xi’an, China \\ chengjing@nwpu.edu.cn \\ Jerry Gao
Department of ComputerEngineering
San Jose State University,
San Jose, USA
jerry.gao@sjsu.edu

\author{
Yi-an Zhu \\ School of Computer Science \\ Northwest Polytechnical University, \\ Xi'an, China \\ zhuya@nwpu.edu.cn \\ Tao Wang \\ School of Software Engineering \\ Northwest Polytechnical University \\ Xi'an, China \\ 850767660@qq.com
}

\author{
Tao Zhang \\ School of Software Engineering \\ Northwest Polytechnical University \\ Xi’an, China \\ tao_zhang@nwpu.edu.cn
}

\begin{abstract}
Location-based services are growing in popularity due to the ubiquity of smartphone users. The availability and validity of location-based services are often effected by mobile user location contexts, which make mobile location-based services testing becomes one urgent and challenging issue. In this paper, we analyze location related features for location-based mobile apps. Then some test strategies are proposed to test those location related features and characteristics. Moreover, a case study is reported to describe our test approaches and test steps in details.
\end{abstract}

\section{CCS Concepts}

- Software and its engineering Software testing and debugging

- Human-centered computing Mobile computing

Keywords - Location-based services; mobile testing; mobile apps; test approach;

\section{INTRODUCTION}

Location-based mobile apps provide many interesting and convenient location-based services (LBS) and functions, and bring many surprising and exciting user experiences[1]. For example, mobile tourism app "Tripadvisor (tripadvisor.com)" helps to find nearby hotels and restaurants; mobile social app "Momo (immomo.com)" helps to find nearby friends; and mobile game "Life is Crime (redrobot.com)" make mobile players to fight with other players in the same location contexts.

Mobile location-based services have been identified as the one of most important features of mobile app services [2], and have become one hot research topic in mobile computing domains. In the recent years, there have been a number of published research papers addressing LBS. However, most papers primarily focus on infrastructure [3,4], positioning techniques [5], location privacy preserving [6,7], and other areas.

Till now, there are a few publications discussing mobile LBS testing. There is a lack of systematic and effective test approaches for test engineers to address mobile LBS testing. For mobile LBS testing, test engineers often are confused by following questions:

1) How to select and test location contexts form wide areas?

2) How to test location related information and services?

3) How to test moving objects with moving paths?

4) How to test location related interactive behaviors between multiple mobile users and objects?
Goal of this work is to provide an answer to those urgent questions. We analyze features of location-bases mobile apps firstly. Then some key test strategies and test approaches are proposed for solving above questions, and a case study is also presented to describe test approaches in details. Finally, concluding remarks and future research directions are given.

\section{LOCATION-RELATED FEATURES}

Location-based mobile apps have some special locationrelated features, such as map, location contexts, location objects, location-based information, location-based services and behaviors, and moving patterns and paths.

Map is the basic component of location-based mobile apps, which displays location contexts, and positions of mobile users and other location objects. Most of mobile LBS use third-party map service, such as Google Maps, Apple Maps, Baidu Maps, etc.

Location contexts represent different physical positions, mobile environments, and location-based user contexts, which affect information, behaviors and services provided by mobile Apps.

Location objects are objects with geographical positions, which may represent hotels, restaurants, mobile users, cars, or sensors in mobile apps. Location objects may be static or moving, provide static or dynamic information, and interact with nearby other location objects.

Location-based information is recommended and provided based on the geographical position of mobile users, such as position information, nearby business information, and local advertisements and news.

Location-based services include basic location services and domain related location services. There are three mainly basic location services, including map service, position service, and navigation service. There are different domain related location services, for example,location-based advertisement service, search nearby friend service, report nearby jam service, etc.

Mobile users and moving objects have various moving patterns and paths, which will change geographical positions of mobile users and location objects, and also change location relations between mobile users and location objects. Then moving patterns and paths bring many uncertainties for location-related mobile apps.

In table 1, we analyze location related features for four popular location-based mobile apps: TripAdvisor, Waze, Momo, and Life is Crime. 
TABLE I. LOCATION-BASED MOBILE APP FEATURES

\begin{tabular}{|c|c|c|c|c|c|}
\hline \multicolumn{2}{|c|}{ Mobile Apps } & TripAdvisor & Waze & Momo & Life is Crime \\
\hline \multicolumn{2}{|c|}{ Web Site } & tripadvisor.com & waze.com & $\begin{array}{l}\text { immomo.co } \\
\mathrm{m}\end{array}$ & redrobot.com \\
\hline \multicolumn{2}{|c|}{ Domain } & Business & Traffic & $\begin{array}{l}\text { Social } \\
\text { network }\end{array}$ & Fight Game \\
\hline \multicolumn{2}{|r|}{ MAP } & Yes & Yes & No & Yes \\
\hline \multicolumn{2}{|c|}{ Location Area } & $\begin{array}{l}\text { About } 39 \\
\text { Countries }\end{array}$ & $\begin{array}{l}\text { About } 190 \\
\text { countries }\end{array}$ & China & $\begin{array}{l}\text { About } 120 \\
\text { countries }\end{array}$ \\
\hline \multirow{2}{*}{$\begin{array}{l}\text { Loc } \\
\text { ation- } \\
\text { based } \\
\text { Object }\end{array}$} & $\begin{array}{l}\text { Static } \\
\text { Objects }\end{array}$ & $\begin{array}{c}\text { Restaurants, } \\
\text { Hotels, Tourist spots, } \\
\text { Malls, and Event } \\
\text { centers } \\
\end{array}$ & $\begin{array}{c}\text { Traffic jams, } \\
\text { Accidents, Cameras, } \\
\text { Police, Dangers, } \\
\text { Gas stations, }\end{array}$ & No & $\begin{array}{c}\text { Houses, } \\
\text { Shops, Streets, }\end{array}$ \\
\hline & $\begin{array}{l}\text { Moving } \\
\text { Objects }\end{array}$ & Mobile users & Auto, friends & $\begin{array}{l}\text { Nearby } \\
\text { friends }\end{array}$ & $\begin{array}{c}\text { Mobile users, } \\
\text { Polices }\end{array}$ \\
\hline \multicolumn{2}{|c|}{$\begin{array}{l}\text { Location-based } \\
\text { Information }\end{array}$} & $\begin{array}{r}\text { Position } \\
\text { information, } \\
\text { Business } \\
\text { information }\end{array}$ & $\begin{array}{c}\text { Information } \\
\text { about traffic jams, } \\
\text { accidents, cameras, } \\
\text { police, dangers, and } \\
\text { gas stations, } \\
\end{array}$ & $\begin{array}{l}\text { Information } \\
\text { about nearby } \\
\text { friends }\end{array}$ & No \\
\hline \multirow{3}{*}{$\begin{array}{r}\text { Basic } \\
\text { location } \\
\text { Service }\end{array}$} & $\begin{array}{l}\text { Map } \\
\text { service }\end{array}$ & $\begin{array}{r}\text { Third party map, } \\
\text { such as Google Map }\end{array}$ & $\begin{array}{ll}\text { Own } & \text { map } \\
\text { service } & \\
\end{array}$ & No & $\begin{array}{l}\text { Own map } \\
\text { service }\end{array}$ \\
\hline & $\begin{array}{l}\text { Position } \\
\text { service }\end{array}$ & GPS & GPS & GPS & GPS \\
\hline & $\begin{array}{l}\text { Navigati } \\
\text { on } \\
\text { Service }\end{array}$ & Yes & Yes & No & No \\
\hline \multicolumn{2}{|c|}{$\begin{array}{l}\text { Domain-related } \\
\text { Location Services }\end{array}$} & $\begin{array}{l}\text { Search nearby } \\
\text { object service }\end{array}$ & $\begin{array}{l}\text { Report nearby } \\
\text { event services, } \\
\text { Display nearby } \\
\text { friend service }\end{array}$ & $\begin{array}{l}\text { Search } \\
\text { nearby user } \\
\text { service }\end{array}$ & $\begin{array}{l}\text { Fight with } \\
\text { nearby players }\end{array}$ \\
\hline \multicolumn{2}{|c|}{ Mobile patterns } & On feet, By car & By car & $\begin{array}{l}\text { On feet, By } \\
\text { car }\end{array}$ & $\begin{array}{l}\text { On feet, By } \\
\text { car }\end{array}$ \\
\hline
\end{tabular}

\section{TEST STRATEGIES AND APPROACHES}

There are four key steps for testing location-based mobile apps: 1) select mobile test devices; 2) select and test location contexts; 3) test location objects, location-based services and behaviors; 4) test moving patterns and paths. In this section, we use Waze as an example to explain how to test location-based mobile apps in details.

\section{A. Select and prioritize mobile test devices}

There are thousands of mobile devices with diverse appearances, architectures, and platforms. It is impossible to test location-based mobile apps on all thousands of devices with restricted test resources. There are two main strategies for selecting mobile test devices as below.

a) Select a set of mobile test devices to cover all compatibility features;

b) Select and test a set of popular mobile devices;

Those two strategies should be combined to select mobile test devices. Higher coverage helps to discover more faults, and testing popular devices helps to reduce fault damages on mobile users. In table 2, we list 10 mobile devices selected form Amaze to test "Waze", those test devices contain diverse compatibility features, and also have higher market shares.

\section{B. Select and test location contexts}

Location-based mobile apps are used in wide areas, and then only limited location contexts are selected to test because of restricted test resources. We select and test location contexts according to below strategies:

a) Select and prioritize the location contexts containing more location objects;

b) Select and prioritize the location contexts appearing more mobile users;

c) Select a set typical user location contexts;

d) Select a set of location contexts with diversity using environments;

The location contexts including more location objects and mobile users are selected and tested to achieve higher test coverage and find more bugs. Typical user location contexts represent mobile apps frequently used in those location contexts. Diversity using environments mean different position environments (such as indoor position, GPS position, and network position) and network environments (such as 2G, 3G, 4G, and WiFi).

Normally, we randomly generate a large number of test location contexts considering location distributions of mobile users and location objects firstly. Then we select and prioritize a small set of location contexts using above strategies according to test resources and costs.

For example, we generate 200 initial location contexts for Waze. And then we select a set of 5 location contexts as test location contexts, as shown in table 3 . The number of objects and mobile users are changing, so we calculate the average number of objects and mobile users for every location context. Waze is used 
for providing navigation services, and then user contexts are designed to test Waze in different road contexts, such as: street,

high way, country road, beach path, etc.

TABLE II. SELECTED MOBILE TEST DEVICES FOR WAZE

\begin{tabular}{|c|c|c|c|c|c|c|}
\hline $\begin{array}{l}\text { Device } \\
\text { Models }\end{array}$ & $\begin{array}{l}\text { Manufa } \\
\text { cturers }\end{array}$ & $\begin{array}{l}\text { Mobile } \\
\text { platforms }\end{array}$ & $\begin{array}{l}\text { Scree } \\
\text { n sizes } \\
\text { (inche } \\
\text { s) }\end{array}$ & $\begin{array}{r}\text { Screen } \\
\text { resolutions } \\
\text { (pixels) }\end{array}$ & $\begin{array}{c}\text { R } \\
\text { AM } \\
\text { B) }\end{array}$ & $\begin{array}{l}\text { Wireless } \\
\text { network }\end{array}$ \\
\hline $\begin{array}{l}\text { Apple Iphone } \\
5 \mathrm{~s}\end{array}$ & Apple & IOS 7.0 & 4.0 & $\begin{array}{l}1136 * 64 \\
0\end{array}$ & 1 & $\begin{array}{l}\text { 4G,3G,WI } \\
\text { FI }\end{array}$ \\
\hline $\begin{array}{l}\text { Apple IPhone } \\
6 \mathrm{~s}\end{array}$ & Apple & IOS 9 & 4.7 & $\begin{array}{l}1334 \times 75 \\
0\end{array}$ & 2 & $\begin{array}{l}\text { 4G,3G,WI } \\
\text { FI }\end{array}$ \\
\hline $\begin{array}{l}\text { Apple IPhone } \\
6 s \text { plus }\end{array}$ & Apple & IOS 9 & 5.5 & $\begin{array}{l}1920 \times 10 \\
80\end{array}$ & 2 & $\begin{array}{l}\text { 4G,3G,WI } \\
\text { FI }\end{array}$ \\
\hline $\begin{array}{l}\text { Moto x Pure } \\
\text { Edition }\end{array}$ & $\begin{array}{l}\text { Motorol } \\
\text { a }\end{array}$ & $\begin{array}{l}\text { Android OS } \\
5.1\end{array}$ & 5.7 & $\begin{array}{l}2560 \times 14 \\
40\end{array}$ & 3 & $\begin{array}{l}\text { 4G,3G,WI } \\
\text { FI }\end{array}$ \\
\hline OnePlus Two & $\begin{array}{l}\text { Microm } \\
\mathrm{ax}\end{array}$ & $\begin{array}{l}\text { Android OS } \\
5.1\end{array}$ & 5.5 & $\begin{array}{l}1920 \times 10 \\
80\end{array}$ & 4 & $\begin{array}{l}\text { 4G,3G,WI } \\
\text { FI }\end{array}$ \\
\hline $\begin{array}{r}\text { Samsung } \\
\text { GALAXY S6 } \\
\end{array}$ & $\begin{array}{l}\text { Samsun } \\
\mathrm{g}\end{array}$ & $\begin{array}{l}\text { Android OS } \\
5.0 \\
\end{array}$ & 5.1 & $\begin{array}{l}2560 \times 14 \\
40 \\
\end{array}$ & 3 & $\begin{array}{l}\text { 4G,3G,WI } \\
\text { FI }\end{array}$ \\
\hline $\begin{array}{l}\text { One Touch } \\
\text { Idol } 3\end{array}$ & $\begin{array}{l}\text { ALCAT } \\
\text { EL }\end{array}$ & $\begin{array}{l}\text { Android OS } \\
5.0\end{array}$ & 4.7 & $\begin{array}{r}720 \\
\times 1280 \\
\end{array}$ & 5 & $\begin{array}{l}\text { 4G,3G,WI } \\
\text { FI }\end{array}$ \\
\hline Moto G & $\begin{array}{l}\text { Motorol } \\
\text { a }\end{array}$ & $\begin{array}{l}\text { Android OS } \\
4.3\end{array}$ & 4.5 & $\begin{array}{l}1280 \times 72 \\
0\end{array}$ & 1 & $\begin{array}{l}\text { 2G,3G,WI } \\
\text { FI }\end{array}$ \\
\hline $\begin{array}{c}\text { Samsung } \\
\text { GALAXY Note } 5\end{array}$ & $\begin{array}{l}\text { Samsun } \\
\text { g }\end{array}$ & $\begin{array}{l}\text { Android OS } \\
5.1\end{array}$ & 5.7 & $\begin{array}{l}2560 \times 14 \\
40\end{array}$ & 4 & $\begin{array}{l}\text { 4G,3G,WI } \\
\text { FI }\end{array}$ \\
\hline $\begin{array}{l}\text { Grand X } \\
\text { Max }^{+}\end{array}$ & ZTE & $\begin{array}{l}\text { Android OS } \\
4.4\end{array}$ & 6 & $\begin{array}{l}1280 \times 72 \\
0\end{array}$ & 2 & $\begin{array}{l}\text { 2G,3G,WI } \\
\text { FI }\end{array}$ \\
\hline
\end{tabular}

TABLE III. SELECTED LOCATION CONTEXTS FOR WAZE

\begin{tabular}{|c|c|c|c|c|}
\hline $\begin{array}{c}\text { Locat } \\
\text { ion } \\
\text { contexts }\end{array}$ & $\begin{array}{r}\text { Locatio } \\
\text { n positions }\end{array}$ & $\begin{array}{r}\text { Averag } \\
\text { e number } \\
\text { of location } \\
\text { objects }\end{array}$ & $\begin{array}{c}\text { Avera } \\
\text { ge } \\
\text { number } \\
\text { of mobile } \\
\text { users }\end{array}$ & $\begin{array}{r}\text { Desc } \\
\text { riptions }\end{array}$ \\
\hline $\begin{array}{l}\text { New } \\
\text { York }\end{array}$ & $\begin{array}{c}40.7142 \\
70,- \\
74.005970\end{array}$ & 5845 & 20156 & $\begin{array}{l}\text { Grea } \\
\text { t city }\end{array}$ \\
\hline $\begin{array}{c}\text { San } \\
\text { Francisco }\end{array}$ & $\begin{array}{c}9.99299 \\
0,- \\
84.129340\end{array}$ & 1825 & 4099 & $\begin{array}{l}\text { Big } \\
\text { city }\end{array}$ \\
\hline $\begin{array}{l}\text { San } \\
\text { Jose }\end{array}$ & $\begin{array}{c}9.93333 \\
0,- \\
84.083330\end{array}$ & 1547 & 3784 & $\begin{array}{l}\text { Sma } \\
\text { ll city }\end{array}$ \\
\hline $\begin{array}{l}\text { Burnt } \\
\text { Corn }\end{array}$ & $\begin{array}{c}31.5534 \\
90, \\
- \\
87.160260\end{array}$ & 48 & 154 & $\begin{array}{l}\text { Tow } \\
\mathrm{n}\end{array}$ \\
\hline $\begin{array}{l}\text { San } \\
\text { Diego }\end{array}$ & $\begin{array}{c}32.7153 \\
3,- \\
117.157260\end{array}$ & 746 & 3529 & $\begin{array}{l}\text { Beac } \\
\mathrm{h}\end{array}$ \\
\hline
\end{tabular}

C. Test location objects and location-based services

In mobile apps, there are different kinds of location objects, which one has thousands, even millions of instances. Every location object provides different information, and has some special behaviors. Then we should test every location object, and its information and behaviors.

For Waze, there are some type of location objects, such as Traffic jams, Accidents, Cameras, Police, Dangers, and Gas stations. We design a set of test cases to check if the positions and information of location objects are right.

There are three mainly basic location services: map service, position service, and navigation service. Position service is provided by mobile platform. Most of location-based apps integrate and use the third party maps and navigation services, which have been tested sufficiently.

However Waze provides map service and navigation service, then some test cases are designed to test Waze map service, such as: zoom in, zoom out, moving. Navigation service is more difficult to test for considering many complex factors, such as traffic jams, dangers, road situations, etc.

Every location-based mobile app also has some special domain-related location services, which should be paid more attentions on testing. Waze provides some domain related location services, such as: report nearby police, report nearby jam, report nearby danger, display nearby friend, etc. We design test cases for every kind of domain-related location services, and those test cases are tested in various location contexts.

D. Test moving patterns and paths

When a mobile user is moving, his location context is continually changing, the wireless network is unstable, and his position is continuously changed. That brings many uncertainties for location-based mobile apps. There are three key factors for design test cases to test moving patterns of mobile users and moving objects.

\section{1) Moving paths}

Moving path for mobile user represents continually changing location contexts, wireless network environments, and position environments. There are some typical kinds of moving paths, such 
as highway, street, alley, hill pathway, seaside pathway, etc. There are three basic strategies to test moving paths: 1) selecting all kind of moving paths; 2) selecting and prioritizing moving paths with more mobile users; 3) selecting moving paths with complicated network and position environments. For Waze, we select 10 typical moving paths, as shown in Table 4.

\section{2) Moving ways and speed}

There are some classic moving ways, such as on feet, by car, by train, and by plant. Every moving way has special speed ranges, and then boundary value method can be used to design test cases. For example, the speed of car is normal between $0-65 \mathrm{~m} / \mathrm{h}$. Then we separately test speed of mobile users in Waze on $10 \mathrm{~m} / \mathrm{h}, 40$ $\mathrm{m} / \mathrm{h}$ and $65 \mathrm{~m} / \mathrm{h}, 80 \mathrm{~m} / \mathrm{h}$.

TABLE IV. SELECTED MOVING PATHS FOR TESTING WAZE

\begin{tabular}{|c|c|c|c|c|c|}
\hline $\begin{array}{l}\text { Location } \\
\text { context }\end{array}$ & Path name & Start position & End position & $\begin{array}{l}\text { Path } \\
\text { type }\end{array}$ & $\begin{array}{l}\text { Path length } \\
\text { (meter) }\end{array}$ \\
\hline New York & Murray Street & $\begin{array}{l}40.715029, \\
-74.013122\end{array}$ & $\begin{array}{l}40.712927, \\
-74.007248\end{array}$ & Street & 692 \\
\hline New York & $\begin{array}{l}\text { Brooklyn-Battery } \\
\text { Tunnel }\end{array}$ & $\begin{array}{l}40.705172, \\
-74.015101\end{array}$ & $\begin{array}{l}40.707148, \\
-74.014924\end{array}$ & Tunnel & 220 \\
\hline $\begin{array}{c}\text { San } \\
\text { Francisco }\end{array}$ & Central Freeway & $\begin{array}{c}37.771685 \\
-122.423245\end{array}$ & $\begin{array}{c}37.769222, \\
-122.410810\end{array}$ & Freeway & 1407 \\
\hline $\begin{array}{c}\text { San } \\
\text { Francisco }\end{array}$ & Duboce Avenue & $\begin{array}{c}37.769319, \\
-122.429280\end{array}$ & $\begin{array}{c}37.769185 \\
-122.433185\end{array}$ & Avenue & 433 \\
\hline San Jose & $\begin{array}{l}\text { Guadalupe } \\
\text { Parkway }\end{array}$ & $\begin{array}{c}\text { 37.370067, } \\
-121.926628\end{array}$ & $\begin{array}{c}37.260626 \\
-121.859090\end{array}$ & Parkway & 15604 \\
\hline San Jose & $\begin{array}{l}\text { Blossom Hill } \\
\text { Road }\end{array}$ & $\begin{array}{c}37.257180, \\
-121.794240\end{array}$ & $\begin{array}{c}37.235722, \\
-121.977623\end{array}$ & $\begin{array}{c}\text { Hill } \\
\text { Road }\end{array}$ & 20494 \\
\hline Burnt Corn & $\begin{array}{l}\text { Sand Bottom } \\
\text { Road }\end{array}$ & $\begin{array}{l}31.553490, \\
-87.160260\end{array}$ & $\begin{array}{l}31.582154, \\
-87.213281\end{array}$ & $\begin{array}{l}\text { Country } \\
\text { Road }\end{array}$ & 6690 \\
\hline Burnt Corn & $\begin{array}{l}\text { Conecuh Country } \\
15\end{array}$ & $\begin{array}{l}31.550050, \\
-87.159551\end{array}$ & $\begin{array}{l}31.334568, \\
-87.150989\end{array}$ & $\begin{array}{l}\text { State } \\
\text { Road }\end{array}$ & 23937 \\
\hline San Diego & Pacific Highway & $\begin{array}{c}32.711206, \\
-117.171088\end{array}$ & $\begin{array}{c}32.766942, \\
-117.208478\end{array}$ & $\begin{array}{l}\text { Highwa } \\
\mathrm{y}\end{array}$ & 7465 \\
\hline San Diego & Sea World Drive & $\begin{array}{c}32.770622, \\
-117.204927\end{array}$ & $\begin{array}{c}\text { 32.761817, } \\
-117.227897\end{array}$ & $\begin{array}{l}\text { Sea } \\
\text { Drive }\end{array}$ & 2730 \\
\hline
\end{tabular}

\section{3) Location relations}

Because positions of mobile users and moving objects are continually changing, the location relations between mobile users and moving objects are changing. Changing location relations will affect location-related interactive behaviors between mobile users and moving objects.

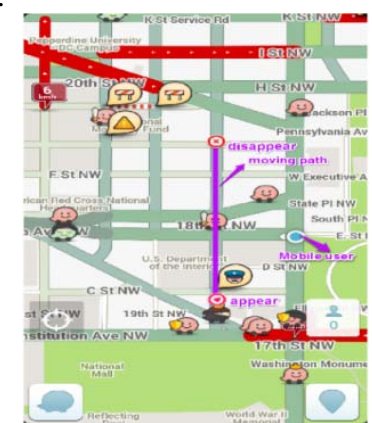

Fig.1. A test case for location relations

The typical changing patterns of location relations include appearing, disappearing, approaching, and distancing. Appearing means a location object is activated, and then enter location context of mobile user. Disappearing means a location object is deactivated, and then exit location context of mobile user. Approaching means a location object is nearing mobile user. Distancing means a location object is far away from mobile user. Test cases should be designed to test every type changing patterns of location relations, and also to test the combinations of above four patterns.
Waze shows location relations between mobile users and nearby friends. As shown in Figure 1, a test case is designed to test changing location relations between one mobile user and his friend. In the test case, the friend appears firstly, move closely to the mobile user, and then move far from the mobile user, and disappear at last. So this test case combines all four type of location relations: appearing, approaching, distancing, and disappearing.

\section{RELATED WORKS}

Nowadays, mobile LBS have become one hot research topic in mobile computing domain, and many papers have been published to address different areas in mobile LBS. A conceptual framework for personalized location-based tourism apps leveraging semantic web to enhance tourism experience is proposed by Mahmood [3]. Al Nabhan presents a new strategy in achieving highly reliable and accurate position solutions fulfilling the requirements of LocationBased Services (LBS) pedestrians' applications [8].

The location privacy issues are serious for LBS. Zhang et al. propose an LBS privacy-quantifying framework and used the mutual information metric to measure adversary's information gain in his inference attacks [9]. An adaptive location privacypreserving the system is presented, which allows a user to control the level of privacy disclosure with different quality of locationbased services [10]. Freudiger et al use Kullback-Leibler divergence between prior and posterior distributions to measure the ability of the adversary to guess the probability of each user visiting specific POIs [11]. 
However, there are a few publications about mobile LBS testing. Jerry Gao discusses the issues and difficulties of mobile LBS testing [12]. Ke Zhai proposes a suite of metrics for prioritizing test cases for regression testing of LBS [13]. Nigel Davies proposes a hybrid test and simulation environment for evaluating system- and network-related issues in location-based applications. Huichun Chu proposes a two-tier test approach for location-aware mobile learning systems [14]. Solveig Bjørnestad presents an example study about evaluation of a location-based mobile news reader [15]. Jiang Yu analyzes test requirements, and presents a scalable testing framework for mobile LBS [16].

We have proposed an initial test model [17] and some test coverage metrics [18] for function services of mobile LBS. In this paper, we present some test strategies about selecting test devices, location context, location objects, and moving patterns. And then the test approaches are described in details using a case study.

\section{CONCLUSION}

In this paper, we discuss test approaches and test steps for location-based mobile apps, and some test strategies are proposed about how to select test devices, location contexts, location objects and location-based services, and moving patterns and paths. We also provide a case study to describe our test approaches in details. We hope our approaches are useful for test engineers to design test cases for location-based mobile apps.

\section{ACKNOWLEDGMENTS}

This research project was supported by National Natural ScienceFoundation of China (Program No. 61103003).

This research project was supported by Shaanxi Province Industrial Science and Technology Research Foundation (Program No. 2016GY-100).

\section{REFERENCES}

[1] Adrian Holzera, and Jan Ondrusb. "Mobile application market: A developer's perspective”, Telematics and Informatics, 2014, 28(1): pp.22-31.

[2] Sergio Ilarri, Arantza lllarramendi, Eduardo Mena, Amit Sheth, "Semantics in Location-Based Services," IEEE Internet Computing, vol. 15(6), 2011, pp.10-14

[3] Mahmood, F.M., Bin Abdul Salam, Z.A. "A conceptual framework for personalized location-based Services (LBS) tourism mobile application leveraging semantic web to enhance tourism experience", the 3rd IEEE International Conference on Advance Computing (IACC), 2013, pp.287 - 291

[4] Mohammad AL Nabhan, Suleiman Almasri, Vanja Garaj, Wamadeva Balachandran, and Ziad Hunaiti, "Client-Server Based LBS Architecture: A Novel Positioning Module for Improved Positioning Performance”, International Journal of Handheld Computing Research, vol.1(3), 2010, pp.1-18
[5] Chen HuangChi, Chen YuJu, Chen ChihYung, Wang Shuming T., Yang JenPin, Hwang ReyChue, "A New Indoor Positioning Technique Based on Neural Network”, Advanced Science Letters, Vol.19(5), July 2013, pp. 2029-2033

[6] K. G. Shin, X. Ju, Z. Chen, and X. Hu, "Privacy protection for users of location-based services," IEEE Wireless Communications, vol.19(1), 2012, pp. 30-39.

[7] Zhu, I., K.-H. Kim, and P. Mohapatra. "An Adaptive PrivacyPreserving Scheme for Location Tracking of a Mobile User." in IEEE International Conference on Sensing, Communication, and Networking. New Orleans, USA, 2013, no pp. 9.

[8] AL Nabhan, Mohammad Mousa, "Adaptive, reliable, and accurate positioning model for location-based services”, Brunel University School of Engineering and Design PhD Theses, 2009

[9] X. J. Zhang, X. L. Gui, Z. C. Feng, F. Tian, S. Yu, and J. Q. Zhao, A quantifying framework of query privacy in location-based service, (in Chinese), Journal of Xi'an Jiaotong University, vol. 48, no. 2, pp. 8-13, 2014.

[10] Zhu, I., K.-H. Kim, and P. Mohapatra. "An Adaptive PrivacyPreserving Scheme for Location Tracking of a Mobile User." in IEEE Internation Conference on Sensing, Communication, and Networking. New Orleans, USA, 2013, no pp. 9.

[11] J. Freudiger, R. Shokri, and J.-P. Hubaux, Evaluating the privacy risk of location-based services, in Proc. the 15th Int'l Con. on Financial Cryptography and Data Security, Gros Islet, Saint Lucia, 2012, pp. 31-46.

[12] Jerry Gao, X. Bai, W. T. Tsai, and T. Uehara, "Mobile application testing: a tutorial”, IEEE Computer, vol.47(2), 2014, pp.26-35

[13] Ke Zhai, Bo Jiang, Chan, W.K., "Prioritizing Test Cases for Regression Testing of Location-Based Services: Metrics, Techniques, and Case Study," IEEE Transactions on Services Computing, 2014, vol.7, no.1, pp.54-67

[14] Hui-Chun Chua, Gwo-Jen Hwangb, Chin-Chung Tsaib, Judy C.R. Tsengc, "A two-tier test approach to developing location-aware mobile learning systems for natural science courses”, Computers \& Education, vol.55(4), 2010, pp.1618-1627

[15] Bjornestad, S., Tessem, B., Nyre, L., "Design and Evaluation of a Location-Based Mobile News Reader," 4th IFIP International Conference on New Technologies, Mobility and Security (NTMS), 2011, pp.7-10

[16] Yu J, Tappenden A, Miller J et al., "A scalable testing framework for location-based services," journal of computer science and technology, vol.22(2),2009,386-44

[17] Oum-EI-Kheir Aktouf, Tao Zhang, Jerry Gao, Tadahiro Uehara, "Testing location-based function services for mobile applications", The First International Workshop on Mobile Cloud TaaS (MCTaaS 2015), 2015,. pp.564-572

[18] Tao Zhang, Jerry Gao, Oum-EI-Kheir Aktouf. "Test Model and Coverage Analysis for Location based Mobile Services", The 27th International Conference on Software Engineering and Knowledge Engineering, 2015, pp.348-356 